\title{
No Flexicurity without trade unions: The Danish experience
}

\author{
Philip Rathgeb \\ Department of Politics and Public Administration, Chair of Political Science, especially Policy Analysis \\ and Political Theory, University of Konstanz, Konstanz, Germany. \\ E-mail: philip.rathgeb@uni-kostanz.de
}

\begin{abstract}
The literature of comparative political economy considers the Danish "Flexicurity" model the egalitarian variety of contemporary capitalism. This article, however, contests this common assessment by tracing the gradual policy changes that led to an erosion of its security-related components. Comparing the rise and erosion of the Danish "Flexicurity" model, it argues that the explanation for this reform trajectory lies in the exclusion of the labour movement from the policy-making process. Danish minority governments gained little by involving unions, because they were no longer reliant on an extra-parliamentary channel of consensus mobilisation. Flexible majoritybuilding in the parliamentary arena allowed them to seek their preferred policy output independent from union consent. The onset of the Great Recession therefore allowed governments of the right as well as the left to dismiss the one single actor that mobilised political support for workers at risk of unemployment. Without the involvement of organised labour, the concept of "Flexicurity" cannot live up to its promise of mitigating economic uncertainty on a volatile labour market.
\end{abstract}

Keywords: Flexicurity; Denmark; Labour market policy; Trade unions; Government; Social security

This concept of "Flexicurity" is a way of ensuring that employers and workers feel they have the flexibility, but also the security they need. José Manuel Barroso, 11th President of the European Commission, February 2006.

\section{Introduction}

Denmark was the country where academic and policy-making circles alike believed to have found a model of egalitarian capitalism. Its success in reconciling successful economic performance with high levels of social solidarity was widely 
attributed to a nationally distinct policy formula that has served as the central role model for European progressive reformers of the past two decades: Flexicurity (Martin and Thelen, 2007; Palier and Häusermann, 2008; Martin and Swank, 2012; Bredgaard, 2013; Thelen, 2014). In the Danish case, it can be associated with a "golden triangle" of employment-promoting flexibility, solidarity-enhancing unemployment protection, and training-oriented ALMP (Madsen, 1999, 2002). The liberal component of low job security as well as the social democratic component of inclusive and generous unemployment protection are part of the Danish welfare state legacy and are thus far from new (Emmenegger, 2010). By contrast, the unprecedented expansion of training-based ALMP in the wake of a general transition to activation was the novel response to the economic crisis of the early 1990s and thus completed the "golden triangle" of Flexicurity. In this policy strategy, risk collectivisation rests on welfare state support designed to foster the adaptation of workers' skills to changing markets while providing income security in the event of unemployment at the same time. Conceived in this way, Thelen (2014) comes to the conclusion that Danish Flexicurity should be seen as the egalitarian variety of liberalisation, as it incorporated the social demands of workers with precarious attachments to the labour market.

Following the "golden triangle" definition, however, this article calls into question the egalitarian virtues of the Danish Flexicurity model by tracing a gradual erosion of its security-related components from which precisely the weakest labour market segments benefitted so much. While employers still enjoy high levels of discretion in hiring and firing employees, workers faced cuts in the generosity and coverage of unemployment and social assistance benefits, tightened activation demands for access to benefit payments, and a decline in public resources on training-based ALMP. More specifically, a halving of the benefit duration from four to two years and a doubling in the re-qualification period to one year in tandem with rising unemployment excluded a significant number of unemployed workers from benefit entitlements (Klos, 2014). This decline in welfare inclusiveness was reinforced by a shrinking membership in the voluntary unemployment benefit funds down to 71.5 per cent (Due et al, 2012) and the legislation of a 225-h work requirement for eligibility to social assistance benefits (Denmark Government, 2016). Second, in the area of ALMP, reduced spending on training and increased pressure on the unemployed to take up any job that deemed suitable accelerated the work-first character of activation policies (Jørgensen, 2009). By 2013, for example, the relative spending level on ALMP was by more than one-third lower than the peak level found in the year of 2000. Perhaps even more importantly, however, legislative interventions curtailed the long-term power basis of organised labour by reducing the institutional incentives to become a union member (Ibsen et al, 2013). The breaking of the de facto union monopoly in the administration of the voluntary unemployment insurance (Ghent system) gave rise to the membership growth of alternative unions that do not take part in collective bargaining and reject industrial 
action. Rapidly falling membership rates among the recognised unions thus cast doubt on the future viability of tripartite concertation on which egalitarian policy intervention in the Danish Flexicurity model was built in the first place (EIRO, 2010).

This article adds to the literature of comparative political economy in three interrelated ways. First, empirically, the article sheds new light on the possibilities and pitfalls of a Flexicurity-oriented strategy of welfare state adjustment through a case study of Danish labour market policy from the late 1980s to the mid-2000s. Second, theoretically, it provides an explanation for the Danish reform trajectory by highlighting the crucial role played by inclusive trade unions for the social protection of workers at risk of unemployment. Thanks to high levels of density rates, they integrate the margins of the workforce directly into the labour movement and therefore mobilise political support for them. Third, also theoretically, by returning government strength to the contextual conditions of the policy-making process, it illuminates the opportunities and constraints trade unions face in the policy-making process. When governments are (1) internally united and (2) externally encompassing, they are strong enough to pursue a unilateral reform strategy that would exclude organised labour. On the other hand, when governments lack one of these two properties, they have a powerful incentive to share policy-making authority with unions to mobilise an extra-parliamentary channel of consensus mobilisation. This helps explain why Danish trade unions were successful in mitigating the risk of unemployment when governments were weak (1990s), but not when they were strong (2000s).

My argument proceeds as follows. The next section develops an argument about how the exclusion of inclusive unions by strong governments caused the erosion of the Danish Flexicurity model. Second, I demonstrate my argument through process-tracing with evidence from semi-structured interviews with policy-making elites carried out by the author. Third, the article elaborates on and thereby expands the comparative significance of the Danish experience by discussing the capacity of Swedish governments to put an end to welfare universalism by marginalising the union movement in the reform process. In the conclusion, I discuss the further implications of this article for the study of labour market policy in contemporary capitalism.

\section{A Power-Distributional Framework: Governments and Trade Unions}

Before looking at the theorised relationship between union inclusiveness, government strength, and the distributive outcomes of labour market policy change, it is worth reviewing why a competing explanation based on partisanship cannot account for the erosion of the Danish Flexicurity model. Between 2001 and 2011, the political right managed to gain a clear and united parliamentary majority 
for the first time since 1929, as the right-wing populist Danish People's Party supported the Liberal-Conservative minority government for ten years. This parliamentary majority indeed enabled the Liberal Party (Venstre), the dominant party in government, to attack the institutional position of union power in order to liberate its voters from the social democratic-friendly union movement in favour of alternative unions. Yet, my diachronic research design allows me to cast doubt on a hypothesis derived from differences in partisanship, especially with respect to unemployment protection (see also Klitgaard and Nørgaard, 2014). If anything, in fact, the centre-left coalition under the auspices of the Social Democrats (2011-2015) went further than the political right by legislating modest welfare cuts for benefit recipients to co-finance tax cuts for people in employment (Goul Andersen, 2012). What is puzzling is that welfare cutbacks for the unemployed took place under centre-right and centre-left governments despite the resilience of egalitarian welfare attitudes among the electorate (Larsen, 2008; Larsen and Goul Andersen, 2009). According to nationwide representative surveys conducted in the years of 2000 and 2008, three-quarters of the respondents in both surveys stated that access to unemployment benefits should be a universal social right (Goul Andersen, 2011, p. 16). Moreover, post-electoral survey data of 2011 show that 71 and 79 per cent of the electorate rejected welfare and tax cuts, respectively (Stubager et al, 2013, p. 37, 39). That partisan reformers of the right as well as the left obviously did not respond to the demands of the overwhelming electoral majority is not consistent with a claim based on partisanship.

I contend that the erosion of the Danish Flexicurity model does not result from electoral dynamics and centre-right partisanship per se, but the gradual exclusion of organised labour from the policy-making process. My core argument is therefore that the viability of social solidarity rests on the reliance of governments on the policy-making support of inclusive trade unions. Once the reform capacity of governments gains little by involving trade unions, they cannot be obliged to adhere to the security-related promises of Flexicurity.

\section{Inclusive Unions and Government Strength}

The strategic capacity of the Danish labour movement to advocate inclusive policy demands results from the institutional function of the Ghent system for membership recruitment on the one hand and the encompassing representational focus emerging from high density rates on the other. Both factors of interest formation are closely intertwined, as the Ghent system per se facilitated the direct incorporation of outsiders into the membership base of Danish unions (Rothstein, 1992). Unlike in Continental Europe, the emergence of mass unemployment did therefore not result in declining density rates, because the union-run administration of voluntary benefit funds integrated unemployed workers into the labour movement. In other words, the Ghent system appealed to the margins of the workforce in particular, since it 
established a clear link between trade unions and unemployed workers (see also Clasen and Viebrock, 2008). As a result, the Danish labour movement reflected the second most inclusive union organisation in the OECD, with only Sweden displaying slightly higher density rates in this period (Gordon, 2015).

A view that puts union preferences front and centre, however, ignores the fundamental fact that governments may turn against negotiated reform to exclude organised labour from the policy-making process, irrespective of membership strength and corporatist legacies. This is especially the case in a historically distinct context where unions lose structural power and electoral significance at the same time (Culpepper and Regan, 2014). In other words, the membership-based power resource emphasised by Thelen (2014) and the administrative power position highlighted by Clegg (2012) indeed condition the strategic capacity of unions to speak on behalf of unemployed workers collectively. But it remains the political choice of governments to negotiate with union confederations or pursue reforms unilaterally. This political choice has important implications for the power relationships on the bargaining table. Union exclusion eases the adoption of structural reforms that stimulate an internal devaluation of the economy, while union inclusion requires lengthy and costly political exchanges between the state, capital, and labour.

Scholarship on social pacts pointed to the political conditions under which governments have a strategic incentive to fall back on union support (Baccaro and Lim, 2007; Hamann and Kelly, 2007; Baccaro and Simoni, 2008). Drawing on this literature, I argue that the strength of unions to achieve outsider-oriented concessions rests on the interaction with weak governments. Governments may be too weak to shape policy outputs autonomously, when they are internally divided or lack parliamentary support. Either condition rules out a unilateral reform strategy and may cause a reform deadlock. Weak governments are therefore more responsive to the demands of unions, because they need support from extra-parliamentary actors in the pursuit of consensus mobilisation. Union consent helps to lend legitimacy to reform proposals of weak governments and receive support in the parliamentary arena. To assess the autonomous reform capacity of Danish minority governments, we can look at their partisan composition and vote share in Table 1.

The 1987 election was a serious defeat for the so-called four-leaf clover centreright minority government under Poul Schlüter, thereby creating a hung parliament between two opposing blocs. In consequence, the non-socialist bloc's thin majority relied on the support from the Progress Party. Somewhat surprisingly, the centreright government stayed in office, even though this instable majority situation was aggravated by the 1990 election outcome, where a two-party coalition between the Conservatives and the Liberals reached only 31.8 per cent of the vote. We would expect the presence of such a weak government to create opportunities for unions to influence the policy output, because the 1987 elections impeded the formation of reliable majorities in the parliamentary arena. Labour-inclusive negotiations would mobilise an extra-parliamentary channel for consensus mobilisation to the benefit 
of a government haunted by instable majorities and stubbornly high unemployment rates.

But labour-inclusive reform negotiations have become less important for the reform capacity of governments, when changes in Danish parliamentarianism allowed minority governments to build flexible majorities for their preferred policy output (Green-Pedersen, 2001). Faced by a fragmented and polarised party system, the Social Democratic-led minority governments of the 1990s connected a growing set of policy changes to the negotiation of annual budget laws, which were based on different coalitions for different elements of the budget law. Minority governments therefore enhanced their bargaining position through pragmatic budget negotiations between the key leaders of the political parties, retrospectively called "patchwork agreements". Handled this way, the minority government could pursue cross-bloc agreements, which are hard to influence for organised interests (Blom-Hansen, 2001). Under this condition, the minority government can pursue an agreement with the party that is closest to its ideal policy preference.

During the 2000s, the bargaining position of the political right was significantly strengthened, as the Liberal-Conservative minority government managed to gain a clear and united majority with support from the right-wing populist Danish People's Party. This was a more favourable situation for the pursuit of unilateral reform ambitions relative to the instable centre-right majorities of the late 1980s and early 1990s. The centre-left government that took over from 2011 to 2015 could either build a majority with the left-wing Red-Green Alliance or the support from one of the two dominant centre-right parties, the Liberals or the Conservatives. A decline in the ideological polarisation on welfare state issues facilitated cross-bloc agreements independent from any involvement of organised interests (Arndt, 2014).

The 2015 elections led to the formation of a Liberal-led single-party minority government with a particularly weak electoral support base, as it displayed a vote share of less than 20 per cent. Similar to the Schlüter coalitions of the late 1980s and early 1990s, we should expect a fragmented power base in parliament to induce the Liberal government to pursue union consent to mobilise an extra-parliamentary channel of consensus mobilisation. The next section illustrates that governments were weak in the late 1980s and 1990s, but not until 2015, and how this temporal change constrained the capacity of trade unions to mitigate the risk of unemployment on a volatile labour market.

\section{The Rise and Erosion of Flexicurity}

\section{Union Inclusion and the Rise of Flexicurity}

In the late 1980s, Denmark faced the resurgence of high unemployment (8-10 per cent) and concerns about the "passive nature" of labour market policy. The Danish 
Economic Council and the centre-right coalition under the Prime Minister Poul Schlüter criticised the permissive granting of welfare benefits. In the spring report of the Economic Council (1988) and the government's "White Paper about the structural problems on the labour market" (1989), unemployment was presented as structural, caused by a lack of financial work incentives, a surplus of low-skilled labour, and high minimum wages (Larsen and Goul Andersen, 2009, p. 247).

The centre-right minority government that relied on the parliamentary support from the non-socialist opposition faced difficulties of reaching compromises in the formulation of structural reforms of the labour market and social security (GreenPedersen 2001, p. 60). At the same time, the Social Democrats proved unwilling to compromise on reforms that restrict the rising costs of unemployment benefit receipt with the Conservative-led minority government. In response, Poul Schlüter appointed two commissions to propose institutional changes on the labour market. The Labour Market Commission (Zeuthen Udvalg) consisted of representatives from the employers' and union's associations, municipalities, ministries and parties, while the Social Commission (Sociale Udvalg) included experts only. The national peak-level associations of the employers (DA) and unions (LO) formed a majority on the Zeuthen Commission.

The most significant reason why Poul Schlüter appointed the labour-inclusive Zeuthen Commission was the lacking parliamentary support for the adoption of structural reforms. According to the head of the secretariat of the Zeuthen Commission, Jørgen Rosted, political support from the LO was thus conceived as the most viable option for strengthening the government's power position to achieve a consensus with the opposition. ${ }^{1}$ Power considerations in the face of lacking parliamentary support proved to be more influential than the ideological policy preferences of the minority government. Thus, the weakness of the centreright gave the unions the opportunity to gain policy-making influence. Despite the recommendations made by the Economic Council and the Conservatives, the involvement of the unions at the bargaining table prevented any further cuts in unemployment benefit levels. After lengthy and controversial negotiations, both between and within the labour market organisations, the political exchange between the peak-level associations implied stricter eligibility criteria and the reduction of benefit duration to seven years in return for social investment and training for the (long-term) unemployed (Torfing, 1999). The Labour Market Commission thus paved the way for the welfare-to-work paradigm change in Danish labour market policy by linking the activation of the unemployed to the expansion of training-based ALMP.

The centre-right coalition, however, had to resign in the wake of a scandal in the Ministry of Justice and thus could not legislate the tripartite compromise reached in the Labour Market Commission. Instead, the dissolution of the centre-right coalition led to the formation of a Social Democratic-led government under the leadership of Poul Nyrup Rasmussen. The new centre-left majority government 
adopted the policy recommendations of the pre-legislative commissions through the legislation of the Labour Market Reform I in 1993. In the process of preparing the labour market reform, unions and employers not only played a pivotal role but were also supported in their institutional responsibilities through the establishing of 14 tripartite regional labour market boards to administer and design the regional activation of the unemployed (Etherington and Jones, 2004, p. 29; Martin and Thelen, 2007, p. 26 f.). This institutionalised power in the implementation of ALMP secured labour acquiescence in the paradigm change towards activation as it gave them a strong foothold in the protection of the unemployed (Larsen and Goul Andersen, 2009, p. 250). The combination between, on the one hand, retrenching benefit duration and tightening eligibility criteria while expanding social investment in the realm of activation policies and, on the other, a classical Keynesian economic recovery plan, including temporary leave options, created a labourinclusive consensus around issues that were initially very controversial.

\section{Union Exclusion and the Erosion of Flexicurity}

In contrast to previous minority governments of Denmark, the Liberal-Conservative minority coalition (2001-2011) was supported by the right-wing populist Danish People's Party and was thus able to legislate de facto independently of the opposition. Programmatic unity inside the governing bloc was based on a simple political exchange: the Liberal-Conservative coalition implemented tight immigration policies in return for the support of the Danish People's Party on the coalition's economic policies (Rydgren, 2004, pp. 496-497; Jupskås, 2015, pp. 29-30). Following this line of exchange, the government had cohesive policy preferences and appointed independent expert committees without any formal representation of the trade unions in the area of labour market policy. ${ }^{2}$ Anders Fogh Rasmussen, the main architect behind the government's reform strategy, withdrew several of the recommendations made by the commissions in the face of electoral risks while pursuing a more policy-oriented, neoliberal reform strategy after the elections of 2007, shortly before he left Danish politics to become General Secretary of the NATO in 2009.

The Liberal-Conservative government took office in the wake of an economic boom, budget surpluses, and low unemployment. Given this economic context and the government's vote-seeking strategy, the Liberals refrained from implementing welfare cutbacks in unemployment insurance, but rather shifted the focus to less salient demands such as (1) stronger work incentives for people on social assistance and (2) more competition ("free choice") in the unemployment protection system. Targeted cutbacks for social assistance recipients on the one hand, and the "marketisation" of a labour market policy with stronger work-search requirements for the unemployed on the other, gained momentum in the first half of the 2000s (Goul Andersen and Pedersen, 2007, pp. 15-20). 
Most notably, in 2001, the Minister of Employment and chief ideologue of the Liberals, Claus Hjort Frederiksen, enabled private and cross-occupational unemployment insurance funds to compete for members with the LO-affiliated benefit funds. This institutional reform gave rise to the membership growth of the alternative unions to the detriment of the recognised union movement. Unlike the traditional "red" unions, the alternative "yellow" unions do not take part in collective agreements with employers' associations and reject industrial action, which enables them to provide a cheap dual membership package including unemployment insurance and individual services across all sectors and occupations (Ibsen et al, 2013). Hence, they provide an ideological and cheaper alternative to the traditional unions, while their members still benefit from the collective bargaining system, as sector agreements cover all employees irrespective of union membership (ibid.). Between 2000 and 2014, unionisation among the traditional unions dropped from almost 69 to 60 per cent, while the alternative unions registered a steady membership increase from 2.5 to 9 per cent of the workforce (Ibsen et al, 2015). Membership away from the LO-affiliated unions was closely connected to declining membership in the union-run unemployment benefit funds (EIRO, 2010). Informal lobbying activities from the LO targeted at Claus Hjort Frederiksen and partly the Danish People's Party could not prevent the liberalisation of the union monopoly, ${ }^{3}$ while the employers did not take any part in that discussion. ${ }^{4}$

The period between 2008 and 2011 marked a profound break with the consensual tradition of Danish labour market politics. The climate between the government and the trade unions deteriorated in the wake of the Liberals' turn towards a policyoriented reform strategy. Why, then, did the Liberal Party shift from a vote maximisation to a neoliberal policy path and thereby break with its "winning formula" of the early 2000s? What is sure is that the onset of the Great Recession in autumn 2008 was perceived as a window of opportunity to legitimise unpopular welfare cuts. ${ }^{5}$ Media campaigns about the fiscal crises in Southern Europe and Ireland were conducive to the government's attempt to frame their policy preference as a matter of economic responsibility in hard times. Unlike the economic crisis of the early 1990s, however, the centre-right parties could exploit the onset of the great recession as a policy window by relying on the support of the Danish People's Party.

In the annual budget negotiations of 2008, the government broke its promise to wait for the end of an evaluation period testing the employment performance of 14 municipal pilot job centres to decide about the future reform of the Public Employment Service (PES). Instead, the government decided to transfer the full administrative responsibility of the PES system from the social partners to the municipalities without waiting for the final report on the performance indicators of the municipal job centres. The idea of breaking the union influence in its institutional responsibility over the implementation of activation programmes has 


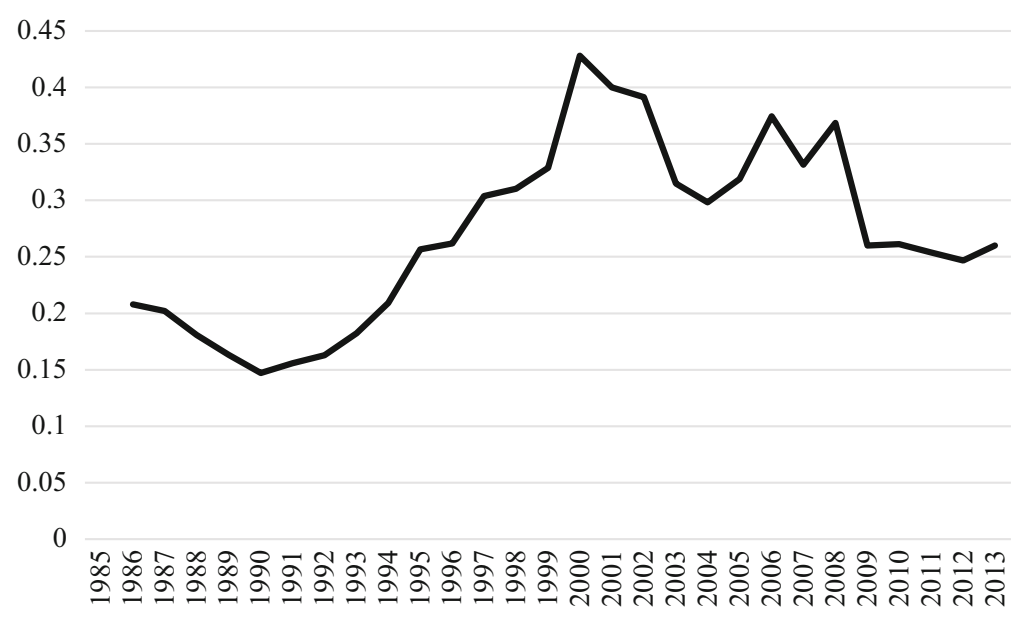

Figure 1: Spending on ALMP in percentage of GDP and divided by the unemployment rate in Denmark, 1986-2013.

long been on the agenda of the Liberal-Conservative government (Christiansen and Klitgaard, 2010). It was at this time, then, that negotiated reform between the Liberal-Conservative government and the trade unions came to a final end. ${ }^{6}$

The full transfer of the administrative responsibility over ALMP from corporatist bodies to the municipalities went hand in hand with a decline in spending (Jørgensen, 2009). Although high levels of spending persisted from a comparative between-case perspective (Bonoli, 2010), the within-case direction reveals a significant decline during the 2000s. By 2013, the relative spending level amounted to 0.26 per cent/GDP per unemployed and was thus by more than one-third lower than the peak level found in the year of 2000 (see Figure 1). According to a study of the University of Aalborg, almost 40 per cent of the unemployed received access to training in the late 1990s, but this figure gradually went down to 6 per cent in the midst of the Great Recession (information.dk, 2010).

In June 2010, the government unilaterally passed an austerity package that amounted to a spending cut of 24 billion Danish Kroner ( $€ 3.21$ billion). The government justified its "reconstruction plan" with the aim of signalling economic stability and meeting the criteria of the European Growth and Stability Pact, as the projected budget deficit amounted to 5.4 per cent/GDP in 2010. Public savings mainly targeted the social protection of workers with high unemployment risks (Ibsen et al, 2013, p. 453): first, the benefit duration was cut from four to two years and the period for calculating the benefit level was extended from 13 weeks to 12 months. Second, the re-qualification period to obtain access to unemployment insurance was doubled from 26 to 52 weeks. Third, the period of the so-called adult education support for unskilled or uneducated persons was halved from 80 to 40 weeks. In response, the LO organised a mass demonstration against the government's austerity package under the title of "No to the austerity package-yes to jobs and education" with an estimated number of 80.000 participants in front of 
the parliament. Their protests did not induce any compensation from the state. On the contrary, in his New Year speech of 2011, Lars Løkke Rasmussen announced the phasing-out of the early retirement scheme (efterl $\phi n)$ and a gradual increase in the statutory retirement age from 65 to 67 years.

A study of the umbrella organisation of unemployment benefit funds $(A K$ Samvirke) shows that 33,900 insured unemployed lost their benefit entitlement in 2013 (Klos, 2014). Moreover, the current tight means-testing character of the social assistance scheme excludes married people from welfare benefits if they own a car or a house, or their spouse is eligible for social assistance (Goul Andersen, 2012). That is to say, the 2010 reform significantly de-universalised the Danish unemployment insurance by cutting the most generous aspects of the system (ibid.), given that net replacement rates for average production workers gradually declined from 82 per cent in 1982 to roughly 60 per cent in 2009 (Van Vliet and Caminada, 2012). Another Achilles heel for the inclusiveness of the Danish Ghent system is declining membership of the voluntary unemployment benefit funds: statistical evaluations registered a gradual loss from almost 80 per cent in 1995 to 71.5 per cent in 2012 (Due et al, 2012, p. 4). In consequence, almost one-third of the workforce is not entitled to income replacement in the event of unemployment.

In a polarised election campaign in November 2011, the Social Democrats and the Socialist People's Party (SF) united with the LO and promised to roll back the welfare cutbacks in their election programme entitled "Fair Solution" (En Fair Lфsning). This plan involved a declaration to find a negotiated crisis response with the unions and the employers. The centre-left bloc won the elections with a narrow majority in October 2011. In the government programme, however, the centre-left minority government under the Social Democratic Prime Minister Helle ThorningSchmidt stated that it would continue the economic reform policy of the previous Liberal-Conservative government. ${ }^{7}$ Therefore, immediately after taking office, the Social Democrats and the SF broke their election promises. So what was the calculation behind this programmatic turnaround? Social Democratic spokespeople pointed to the pivotal position of the market-liberal Social Liberals (RV) within the centre-left coalition, arguing that the RV made their government participation conditional on this written declaration. ${ }^{8}$ Indeed, the RV had already pointed out that they were in favour of the cuts that had been made by the previous government in the election campaign, and they thereby outmanoeuvred the promises of the "Fair Solution" campaign already prior to Election Day. However, this argument about the influential role of the RV is unsatisfactory for the simple reason that the Social Democrats remained the key political operators of the government. If anything, in fact, the Ministry of Finance under the Social Democratic leadership of Bjarne Corydon carved out the economic reform policy of the centre-left government.

Rather than reflecting a divided coalition, the centre-left government started out with a common policy agenda to continue a reform path of orthodox economic adjustment. According to Jens Christiansen, campaign direction of the Social 
Democrats in the 2011 elections, the calculus of the party leadership was to generate economic growth and subsequent votes through the adoption of neoliberal reforms. ${ }^{9}$ Proof of their autonomous reform capacity came in June 2012, when Bjarne Corydon closed down tripartite negotiations with no result as the powerful metalworkers' union (Dansk Metal) in cooperation with LO-affiliated unions opposed his proposal to eliminate two public holidays. The Social Democratic leadership demanded an increase in working time in order to finance future investments in education, job creation, and welfare. The unions, however, were willing to agree to an increase in working days only in times of rising labour demand. In response, the Social Democrats attributed the failure of the talks to the high expectations of the trade unions to a new Social Democratic-led government. Arguably, falling membership rates and competition from alternative unions weakened the political assertiveness of the recognised union movement vis-à-vis the government and employers. ${ }^{10}$ Instead of continuing any further negotiations with the unions, the centre-left government turned to the Liberals and Conservatives to introduce tax cuts for those in employment, partly financed through welfare cuts that were legislated through a reduced indexation mechanism of all cash transfers for the non-employed, except for pensioners. On June 21, the tax reform was supported by the Liberals and the Conservatives, while the employers' association welcomed the reform to the disappointment of the trade unions and the left-wing Red-Green Alliance.

\section{A Revival of Union Involvement?}

In 2015, a Liberal single-party minority government came to power with a vote share of 19.5 per cent. Its weak support base not only resulted from the election outcome per se, but also the unwillingness of the centre-right bloc's remaining parties - the Danish People's Party, the Liberal Alliance, and the Conservative People's Party - to form a coalition with Venstre. Whereas the past LiberalConservative minority government (2001-2011) had been able to rely on backing from the Danish People's Party, the Liberal government (since 2015) has seen itself dependent on parliamentary support from all three centre-right parties or cross-bloc agreements with the left-of-centre parties. The apparent job of Lars Løkke Rasmussen has therefore been to administer a political compromise and not unilateral government intervention.

Against this fragmented balance of power in parliament, the Liberal government refrained from pursuing another attack on the union-run unemployment insurance, but instead relied on recommendations flowing from a commission of experts and social partner representatives. In consequence, the LO successfully extracted one notable concession from the government, that is, the possibility to accumulate benefit eligibility up to one additional year by performing minor jobs during the unemployment benefit period for those unemployed who exhausted the maximum 
benefit duration of two years (Denmark Government, 2016). Still, the core tenets of the 2010 cutback remained in place. This measure was also accompanied by moderate cuts in the benefit levels for university graduates and the stipulation of three waiting days for each year of unemployment benefit receipt. The reform was adopted with support from the Danish People's Party and the Social Democrats. In addition, the government signed a tripartite agreement on the integration of refugees into the labour market. Its key compromise came in April 2016, with the unions blocking what they considered wage dumping through a "phased-in wage" (indslusningsl $\phi n$ ) and extracting resources for skill development, while the employers received the possibility to put refugees into short-term jobs at an apprentice level for up to two years (EIRO, 2015, 2016).

Unlike in the area of unemployment insurance, however, the government was able to muster a right-wing majority for the legislation of social assistance cuts against fierce protests from the opposition and organised labour. The package included a general ceiling on the level of social assistance, targeted cutbacks for residents who had not been in Denmark in seven of the past eight years ("integration allowance"), and an employment requirement of at least $225 \mathrm{~h}$ a year to gain eligibility for social assistance benefits (Denmark Government, 2016). It came into effect in October 2016 and led to an immediate reduction in benefit levels for 33.000 recipients (Der Nordschleswiger, 2016). While the Danish People's Party welcomed the cutback as a way of reducing the attractiveness of Denmark as a host country for refugees, the Liberal Alliance and Conservative People's Party shared the government's ambition to reinforce work incentives. By contrast, the LO chairwoman, Lizette Risgaard, reacted strongly against this legislation and demanded its reversal from the Social Democrats when assuming office again.

In sum, the policy outcomes of union exclusion involved a restructuring of labour market institutions to reduce the generosity and coverage of unemployment and social assistance benefits, make the receipt of benefits contingent on tightened availability and job-search demands, reduce state support for training, and shrink the collective organisation of labour. Even though Danish Flexicurity might well remain the egalitarian variety of liberalisation from an international comparative perspective, it is clear that unilateral government action of the right well as the left tilted the balance towards less security for workers while leaving untouched the flexibility for employers.

\section{Shadow Case Study of Sweden}

If union exclusion is the most adequate explanation for the demise of social solidarity in Danish labour market policy, we should observe a similar causal mechanism in the Ghent countries of Belgium, Finland, and Sweden. All three 
countries display relatively inclusive union movements with administrative roles in unemployment protection and an institutional legacy of welfare universalism. This section therefore investigates the applicability of the argument developed in this paper to Sweden as a prominent representative of the Ghent countries.

Despite strong party-union ties, Swedish Social Democratic-led single-party minority governments from 1994 to 2006 had started to downgrade the unions' influence in the reform process (Obinger et al, 2012). With a vote share of 45.25 per cent from 1994 to 1998, the Social Democratic Party (SAP) was in a hegemonic position and it needed support from only one party among a diverse set of opposition parties. Proof of its capacity to eschew labour acquiescence came in 1995, when the SAP for the first time established cross-class cooperation with the bourgeois Centre Party to obtain support for unilateral reforms in the areas of: (i) job security and (ii) unemployment insurance. In both cases, the SAP moved in the preferred direction of the employers and not the unions (Henkes, 2006). First, the SAP provided for more flexibility in the "hiring and firing" conditions of temporary workers. Second, it concluded an austerity package, which implied a moderate cut in the replacement rate of a number of welfare benefits. This cutback must be placed in the context of the SAP's previous refusal to re-index the unemployment benefit ceiling to inflation, thereby effectively accepting the ongoing decline of benefit generosity.

But the departure from welfare universalism was substantially reinforced when the 2006 elections armed the centre-right parties with a majority of seats for the first time since 1932. Their autonomous reform capacity originated in the unification process of the four traditionally divided bourgeois parties into the socalled Alliance for Sweden (Alliansen) (Aylott and Bolin, 2007). This gave rise to a meticulously planned "make work pay" agenda, which almost invariably ruled out significant political exchanges with the union movement. At its most basic, it implied reductions in access and generosity of social benefits to finance income tax cuts for (low-income and mid-income) workers as well as payroll tax cuts for employers. Handled this way, the official idea was to boost work incentives for people out of work by increasing the gap between wage income and transfer income, while actually pitting the interests of workers with stable jobs ("insiders") against those with high unemployment risks ("outsiders").

Thanks to a united parliamentary majority, the Alliansen could push through an impressive reform programme within two months after its election victory in October 2006. First, the government legislated substantial cuts in unemployment benefit generosity: the replacement rate was cut from 80 to 70 per cent for 200 days of unemployment and to 65 per cent for unemployed with children after 300 days; the maximum benefit ceiling was reduced from 730 to 680 SEK to the level of 2002; the reference period for the calculation of benefit levels was extended from six to 12 months. Second, the government tightened eligibility criteria in various ways. Third, and most controversially, the government increased and differentiated 
the level of fees for membership in the union-run and voluntary unemployment benefit funds (Clasen and Viebrock, 2008, pp. 444-445). As a result, the number of members covered by unemployment insurance fell from 3.8 million to 3.3 million, union density decreased from 75 to 68 per cent, while the LO lost a whole 15 per cent of its membership within one year after reform had taken effect (Kjellberg, 2011). At the same time, in 2006/2007, the Alliansen deregulated fixed-term contracts by doubling the maximum duration of temporary contracts to 24 months and abolishing the obligation on the part of the employer to justify the usage of temporary work.

Perhaps unsurprisingly, all three union confederations heavily protested against this unilateral reform package. For example, in the month before the unemployment insurance reform had taken effect, in December 2006, the Swedish LO organised a petition against the reform signed by 280,000 people. However, the speed of the government in legislating this reform inhibited the mobilising capacity of the labour movement. The "Alliance" lost its majority in the 2010 elections despite a modest increase in the vote, as the radical right-wing Sweden Democrats successfully entered parliament. The loss of a majority and the successful accomplishment of "make work pay" reforms in the government's first tenure restrained the reform frenzy of tax and welfare cuts in the subsequent period. However, the strength of the Reinfeldt cabinet I was sufficient to cause the reinforcement of an ongoing demise of welfare universalism. The Swedish experience therefore resembles what we have found in Denmark, albeit the former experienced more pronounced patterns of union exclusion and, as a result, deeper cutbacks in the generosity and coverage of unemployment protection relative to the latter. When governments were no longer reliant on the unions for successful consensus mobilisation, they emphatically rejected any political exchanges to the detriment of workers at risk of unemployment.

\section{Conclusion}

The Danish experience suggests that the exclusion of encompassing unions is crucial for the demise of social solidarity in labour market policy. This is because high levels of membership provide unions with an inclusive representational outlook towards workers at risk of unemployment. But when governments are internally united and externally strong enough to act unilaterally in the policymaking process, they lack a strategic incentive to pursue political deals with trade unions for successful consensus mobilisation. Their autonomous reform capacity allows them to dismiss the policy demands of trade unions whose electoral significance and structural power have faded over time. The causal significance of union preferences is therefore by no means determinative in an age of declining union power. 
My findings are, of course, limited in their generalisability, given my focus on one single case. But the observations would appear to hold for the other Ghent cases of Belgium, Finland, and Sweden, as they also display encompassing union movements with administrative roles in unemployment protection. The shadow case study of Sweden buttressed the view that union exclusion is necessary for successful attacks on welfare universalism (see also Sjöberg, 2011, p. 228). My empirical findings therefore support the position of Thelen (2014) and Gordon (2015) that high levels of labour organisation create an acute interest in the social protection of workers at risk of unemployment. These theoretical claims about the "solidaristic" role of unions in the distributive outcomes of policy change call for further research, particularly the question as to how trade unions in Continental European and Mediterranean countries respond to the growing emergence of insider-outsider divides. Recent studies suggest that an inclusive representational outlook is not necessarily confined to trade unions with encompassing membership bases. In Austria, for example, the revival of union influence led to a smoothening of institutional divides in unemployment and pension entitlements (Obinger et al, 2012; Rathgeb, 2017). In a similar vein, Naczyk and Seeleib-Kaiser (2015) argue that labour movements in such diverse cases as Belgium, Britain, France, and Germany pushed for an extension in the coverage of supplementary pension schemes to less privileged segments of labour. This claim resonates with findings from Benassi and Vlandas (2016), which document that Southern European unions opened up their bargaining and recruiting strategies to temporary agency workers.

The general implication of this case study is that a decline in union strength and an increase in business power weakened the structural incentive for political parties to provide organised labour with a material compensation for government reforms. A unilateral reform strategy against the interests of unions has also become less risky for the electoral fortunes of national governments, even in such unionised countries as Denmark. But governments cannot impose any agreement on unions, when their autonomous reform capacity is constrained by intra-coalitional divisions or a hung parliament. Under these conditions of weakness, governments continue to face a political incentive to trade policy concessions for union support in the mobilisation of a durable consensus. Differences in the autonomous reform capacity of governments may therefore have a profound impact on the distributive outcomes of the battles around risk protection in contemporary capitalism.

The return of government strength to the contextual conditions of welfare state adjustment may open up new lines of research enquiry. The Great Recession and subsequent formation of the Eurozone's economic governance framework reinforced the pressure on national governments of all partisan complexions to liberalise their labour markets and reduce social spending. To date, it seems that these structural constraints on national policy-making autonomy strengthened the executive power of governments vis-à-vis trade unions (Culpepper and Regan, 2014). But the ongoing demands for liberalisation and austerity might well reach a 
point whereby the parliamentary support and internal unity of governments crumble away and new fora of consensus mobilisation are needed. This would create a reform deadlock situation in which union consent could regain a more prominent role compared to the unilateral reform strategies we could observe during the Great Recession. In the meantime, the decline in union influence will undermine the security-related promises of Flexicurity in Denmark as well as anywhere else.

\section{Acknowledgements}

I would like to thank Hanspeter Kriesi, Pepper Culpepper, Johan Christensen, and Christian Lyhne Ibsen for their helpful comments on earlier drafts of this article. In addition, I acknowledge the conversations about this article with Anja Sahora, Anders Juhl Aagaard, Kasper Ly Netterstrøm, Frederik Hjorth, Lukas Hakelberg, and Max Schaub.

\section{About the Author}

Dr. Philip Rathgeb earned his Ph.D. in Political and Social Sciences at the European University Institute (EUI) in September 2016. His doctoral research was awarded with the Theodor-Körner-Prize. Previously, he studied Political Science at the University of Vienna with an academic minor in Socio-Economics at the Vienna University of Business and Economics. His principal research areas are comparative political economy and welfare state research. Since October 2016, he is a postdoctoral researcher at the Chair of Political Science, especially Policy Analysis and Political Theory, University of Konstanz.

\section{Notes}

1 Interview with Jørgen Rosted, head of the secretariat of the Zeuthen committee, 11 August 2014.

2 Commission of Administrative Structures (2002-2004), Welfare Commission (2004-2007), Labour Market Commission (2007-2009), and Tax Commission (2007-2009).

3 Interview with Jan Kaeraa Rasmussen, Chief Economist of Danish Confederation of Trade Unions (LO), 12 December 2013.

4 Interview with Senior Advisor of Danish Industries (DI), 9 December 2013 and Senior Advisor of Confederation of Danish Employers (DA), 11 December 2013.

5 Interview with Claus Hjort Frederiksen, Liberal Party (Venstre), Minister of Employment (2001-2009) and Minister of Finance (2009-2011), 10 December 2013.

6 Interview with Jan Kaeraa Rasmussen, Chief Economist of Danish Confederation of Trade Unions (LO), 12 December 2013. 
7 Own translation: "The point of departure for the government is the economic policy of the VKgovernment in the widest sense, including the consolidation agreement and the pension reform of spring" (Regeringen, 2011, p. 9).

8 Interview with Mogens Lykketoft, Social Democratic Party (Socialdemokraterne), Speaker of the Danish Parliament (2011-2015), Former Minister of Finance (1993-2000), 13 August 2014.

9 Interview with Jens Christiansen, Managing Director of Advice A/S, Campaign Director for the Social Democratic Party (Socialdemokraterne) in the election of 2011, 12 August 2014.

10 Interview with Political Consultant, Social Democratic Party (Socialdemokraterne), 16 December 2013.

\section{References}

Arndt, C. (2014) Beating social democracy on its own turf: Issue convergence as winning formula for the centre-right in universal welfare states. Scandinavian Political Studies 37(2): 149-170.

Aylott, N. and Bolin, N. (2007) Towards a two-party system? The Swedish parliamentary election of September 2006. West European Politics 30(3): 621-633.

Baccaro, L. and Lim, S.-H. (2007) Social pacts as coalitions of the weak and the moderate. European Journal of Industrial Relations 13(1): 27-46.

Baccaro, L. and Simoni, M. (2008) Policy concertation in Europe: Explaining government's choice. Comparative Political Studies 41(10): 1323-1348.

Benassi, C. and Vlandas, T. (2016) Union Inclusiveness and temporary agency workers: The role of power resources and ideology. European Journal of Industrial Relations 22(1): 5-22.

Blom-Hansen, J. (2001) Organized interests and the state: A disintegrating relationship? Evidence from Denmark. European Journal of Political Research 39(3): 391-416.

Bonoli, G. (2010) The political economy of active labor-market policy. Politics \& Society 38(4): 435-457.

Bredgaard, T. (2013) Flexibility and security in employment regulation: Learning from Denmark. In: K.V.W. Stone and H. Arthurs (eds.) Rethinking Workplace Regulation: Beyond the Standard Contract of Employment. New York: Russell Sage Foundation.

Christiansen, P.M. and Klitgaard, M.B. (2010) Behind the veil of vagueness: Success and failure in institutional reforms. Journal of Public Policy 30(2): 183-200.

Clasen, J. and Viebrock, E. (2008) Voluntary unemployment insurance and trade union membership: Investigating the connections in Denmark and Sweden. Journal of Social Policy 37(3): 433-451.

Clegg, D. (2012) Solidarity or dualization? Social governance, union preferences and unemployment benefit adjustment in Belgium and France. In: P. Emmenegger, S. Häusermann, B. Palier and M. Seeleib-Kaiser (eds.) The Age of Dualization. The Changing Face of Inequality in Deindustrializing Societies. Oxford: Oxford University Press.

Culpepper, P.D. and Regan, A. (2014) Why don't governments need trade unions anymore? The death of social pacts in Ireland and Italy. Socio-Economic Review 12(4): 723-745.

Denmark Government (2016) Denmark's National Reform Programme, April.

Der Nordschleswiger (2016) Neue Sozialhilfeobergrenze: 33.000 Dänen ab 1. Oktober betroffen 23.09.2016.

Due, J.J., Madsen, J.S. and Ibsen, C.L. (2012) A-kassernes medlemstal er stagneret trods krisen. Copenhagen: FAOS, Københavns Universitet.

EIRO (2010) Decline in union density threatens collective bargaining. European Industrial Relations Observatory, 27.01. Available at http://www.eurofound.europa.eu/eiro/2010/12/articles/dk1012019i. htm. Accessed 22 July 2015. 
EIRO (2015) Denmark: Integration of refugees in the labour market. European Industrial Relations Observatory, 17.12. Available at http://www.eurofound.europa.eu/observatories/eurwork/articles/ labour-market-industrial-relations/denmark-integration-of-refugees-in-the-labour-market

EIRO (2016) Denmark: Tripartite agreement on integration of refugees. European Industrial Relations Observatory, 22.04. Available at http://www.eurofound.europa.eu/observatories/eurwork/articles/ working-conditions-industrial-relations/denmark-tripartite-agreement-on-integration-of-refugees

Emmenegger, P. (2010) The long road to Flexicurity: The development of job security regulations in Denmark and Sweden. Scandinavian Political Studies 33(3): 271-294.

Etherington, D. and Jones, M. (2004) Welfare-through-work and the re-regulation of labour markets in Denmark. Capital \& Class 28(2): 19-45.

Gordon, J.C. (2015) Protecting the unemployed: varieties of unionism and the evolution of unemployment benefits and active labour market policy in the rich democracies. Socio-Economic Review 13(1): 79-99.

Goul Andersen, J. (2011) Ambivalent values: Universalism or targeting? Welfare State Attitudes in Denmark. Department of Political Science, Aalborg. CCWS working paper no. 2011-73.

Goul Andersen, J. (2012) Crisis narratives and welfare reform in Denmark. A critical juncture? Aalborg, Denmark: Department of Political Science. Paper prepared for Conference on Labour Markets and Welfare State Research, CARMA \& CCWS, October 2012.

Goul Andersen, J. and Pedersen, J.J. (2007) Continuity and change in Danish active labour market policy: 1990-2007. The battlefield between activation and workfare. Department of Political Science, Aalborg. CCWS working paper no. 54.

Green-Pedersen, C. (2001). Minority governments and party politics: The political and institutional background to the "Danish Miracle". Journal of Public Policy 21(1): 53-70.

Hamann, K. and Kelly, J. (2007) Party politics and the reemergence of social pacts in Western Europe. Comparative Political Studies 40(8): 971-994.

Henkes, C. (2006). Schweden. In: W. Merkel, C. Egle, C. Henkes, T. Ostheim and A. Petring (eds.) Reformfähigkeit der Sozialdemokratie. Herausforderungen und Bilanz der Regierungspolitik in Westeuropa (pp. 272-314). Wiesbaden: VS Verlag für Sozialwissenschaften.

Ibsen, C.L., Due, J. and Madsen, J.S. (2015). Fald i organisationsgraden igen. Copenhagen: FAOS, University of Copenhagen.

Ibsen, F., Høgedahl, L. and Scheuer, S. (2013). Free riders: The rise of alternative unionism in Denmark. Industrial Relations Journal 44(5): 444-461.

Information.dk (2010) Ledige må også selv komme ind i kampen, 12.10.2010. http://www.information. $\mathrm{dk} / 247404$

Jørgensen, H. (2009) From a beautiful swan to an ugly duckling: The renewal of Danish activation policy. European Journal of Social Security 11(4): 337-367.

Jupskås, A.R. (2015) Institutionalised right-wing populism in times of economic crisis: A comparative study of the Norwegian Progress Party and the Danish People's Party. In: H. Kriesi and T.S. Pappas (eds.) European Populism in the Shadow of the Great Recession (pp. 23-40). Colchester: ECPR Press.

Kjellberg, A. (2011). The decline in Swedish union density since 2007. Nordic Journal of Working Life Studies 1(1): 67-93.

Klitgaard, M.B. and Nørgaard, A.S. (2014) Structural stress or deliberate decision? Government partisanship and the disempowerment of unions in Denmark. European Journal of Political Research 52(2): $1-18$.

Klos, M. (2014) 33.900 har mistet deres dagpengeret i 2013, Status for hele 2013. Copenhagen: AK Samvirke.

Larsen, C.A. (2008). The institutional logic of welfare attitudes: How welfare regimes influence public support. Comparative Political Studies 41(2): 145-168. 
Larsen, C.A. and Goul Andersen, J. (2009) How new economic ideas changed the Danish Welfare State: The case of neoliberal ideas and Highly Organized Social Democratic Interests. Governance 22(2): 239-261.

Madsen, K.P. (1999) Denmark: Flexibility, Security, and Labour Market Success. Employment and Training Papers No. 53, ILO Geneva.

Madsen, P.K. (2002) The Danish model of Flexicurity: A paradise - With some snakes. In: H. Sarfati and G. Bonoli (eds.) Labour Market and Social Protections Reforms in Iinternational Perspective: Parallel or Converging Tracks? (pp. 243-265). Aldershot: Ashgate.

Martin, C.J. and Swank, D. (2012) The Political Construction of Business Interests: Coordination, Growth, and Equality. New York: Cambridge University Press.

Martin, C.J. and Thelen, K. (2007) The state and coordinated capitalism. Contributions of the public sector to social solidarity in postindustrial societies. World Politics 60(1): 1-36.

Naczyk, M. and Seeleib-Kaiser, M. (2015) Solidarity against all odds: Trade unions and the privatization of pensions in the age of dualization. Politics \& Society 43(3): 361-384.

Obinger, H., Starke, P. and Kaasch, A. (2012) Responses to labor market divides in small states since the 1990s. In: P. Emmenegger, S. Häusermann, B. Palier and M. Seeleib-Kaiser (eds.) The Age of Dualization. The Changing Face of Inequality in Deindustrializing Countries (pp. 176-200). New York: Oxford University Press.

Palier, B. and Häusermann, S. (2008) The state of the art: The politics of employment-friendly welfare reforms in post-industrial economies. Socio-Economic Review 6(3): 1-28.

Rathgeb, P. (2017) Relying on weak governments: Austrian trade unions and the politics of smoothed dualisation. Austrian Journal of Political Science 45(3): 45-55.

Regeringen (2011) Et Danmark, der står sammen. Regeringsgrundlaget http://www.stm.dk/ publikationer/Et_Danmark_der_staar_sammen_11/Regeringsgrundlag_okt_2011.pdf. Accessed at 22 July 2015.

Rothstein, B. (1992) Labor market institutions and working class strength. In: S. Steinmo, K. Thelen and F. Longstreth (eds.) Structuring Politics. Historical Institutionalism in a Comparative Perspective (pp. 33-56). New York: Oxford University Press.

Rydgren, J. (2004) Explaining the emergence of radical right-wing populist parties: The case of Denmark. West European Politics 27(3): 474-502.

Sjöberg, O. (2011). Sweden: Ambivalent adjustment. In: J. Clasen and D. Clegg (eds.) Regulating the Risk of Unemployment. National Adaptations to Post-industrial Labour Markets (pp. 208-231). Oxford: Oxford University Press.

Stubager, R., Holm, J., Smidstrup, M. and Kramb, K. (2013) Danske vælgere 1971-2011. En oversigt over udviklingen i vælgernes holdninger mv. Det danske valgprojekt, 2. Udgave.

Thelen, K. (2014) Varieties of Liberalization: The New Politics of Social Solidarity. New York: Cambridge University Press.

Torfing, J. (1999) Workfare with welfare: Recent reforms of the Danish welfare state. Journal of European Social Policy 9(1): 5-28.

Van Vliet, O. and Caminada, K. (2012) Unemployment replacement rates: Dataset among 34 welfare states, 1971-2009. An update, modification and extension of the Scruggs' welfare state entitlements data set. Neujobs Special Report January 2012(2). 


\section{Appendix}

See Table 1.

Table 1: Elections and governments in Denmark, 1981-2015

\begin{tabular}{lllll}
\hline Coalition & Period & Governing parties & Type & Vote share (per cent) \\
\hline Centre-right & $1982-1984$ & K, V, CD \& KrF & Minority & 36.4 \\
& $1984-1987$ & K, V, CD \& KrF & Minority & 42.8 \\
& $1987-1988$ & K, V, CD \& KrF & Minority & 38.5 \\
Centre-left & $1988-1990$ & K, V \& RV & Minority & 37.1 \\
& $1990-1993$ & KV \& V & Minority & 31.8 \\
& $1993-1994$ & SD, RV, CD, KrF & Majority & 48.3 \\
Centre-right & $1994-1996$ & SD, RV \& CD & Minority & 42.0 \\
& $1996-1998$ & SD, RV & Minority & 39.2 \\
Centre-left & $2001-2005$ & V , K (\& DF) & Minority & 39.8 \\
Centre-left & $2005-2007$ & V, K (\& DF) & Minority & 40.6 \\
Centre-right & $2007-2011$ & V, K (\& DF) & Minority & 39.3 \\
\hline
\end{tabular}

Notes: SD, Social Democrats; K, Conservative Party; V, Liberal Party; SF, Socialist People's Party; RV, Social Liberals; KrF, Christian Democrats; CD, Centre Democrats; DF, right-wing populist Danish People's Party. 